\title{
Socio-economic Determinants of Cassava Production in Benue State, Nigeria.
}

\author{
Aboajah, F.N. ${ }^{1}$; Onjewu, S.S. ${ }^{2}$; Chia, J.I. ${ }^{3}$; Okeme, S. ${ }^{3}$ \\ ${ }^{1}$ National Root Crops Research Institute, Umudike, Otobi Sub-Station, Otobi, Otukpo LGA. , Benue State \\ ${ }^{2}$ Raw Materials Research and Development Council, Abuja. \\ ${ }^{3}$ Department of Agricultural Extension and Communication, Federal University of Agriculture, Makurdi, Benue State, Nigeria.
}

\begin{abstract}
The study examined the determinants of cassava production in Benue State Nigeria. A total of 180 farmers were selected across the state using multi-stage sampling technique. Data, which comprised information on the socio-economic characteristics and other quantitative variables relevant to the study, were collected using a well structured questionnaire and personal interviews. The social- economic characteristics were analyzed using descriptive statistics such as percentages and frequencies; simple multiple regression technique was used to analyze the production functions of cassava farmers. The results obtained revealed that $R^{2}$ value was 0.419 indicating that $41.9 \%$ of variation in cassava production was accounted for by the variables considered in the study. Specifically, age of the farmers, occupation, household size, farming experience, level of education of farmers, farms size and fertilizer input where all significant and are important variables that affected the production of cassava in the study area. Given the enormous potential of cassava production in the study area, it has become so imperative that youths be encourage to participate effectively in cassava production, seeing that majority of the farmers are aged and will retire from active farming. This is to ensure food security. Effective structure should be put in place for the input and credit facilities provided by the government, this will ensure that these facilities get to those who need it and will in turn help the farmers expand their production. This study, although base in Benue State, may have implications for other States with similar situation. This will help the state meet self-sufficiency in food production and so be able to feed her teeming population.
\end{abstract}

Keywords - Socio-economic, Determinants, Cassava, Farmers, Benue State.

\section{INTRODUCTION}

Cassava is one of the important source of carbohydrate food in Nigerian. Nigerian is the largest producer of cassava in the word with a total output currently put at about 34 million metric tones a year (FAO, 2002). Presently, cassava is primarily product for food especially in the form of Garri, tapioca and fufu for human consumption. But the crop can be processed into several secondary products for industrial market value (World Bank survey, 1981). These products include chips, pellets, flour adhesives, alcohol and starch, which are vital raw materials in the livestock feed, alcohol/ethanol, textile, confectionary, wood, food and soft drinks industries. They are also tradable in the international market.

In view of the serious challenges of feeding world population of over 6.1 billlion people, it has become imperative to pay more attention to food production issues. About 215million (43\%) sub-Saharan African population is chronically undernourished and unless strong action is taken this may increase to round 315million in the year, 2010 (World Food Programs, 1995). If food production is to keep pace with rapid population growth and demand for food, a new and creative approach to agriculture development must be developed.

It is important to emphasize that despite potential benefits stemming from the expansion of the agricultural sector through various government efforts, its overall productivity remain low and the poor performance of agriculture is most clearly evidenced by the low standard of living of these small-scale rural farmers (Dogon-daji, 2006). Cassava offers a particularly significant potential for increasing food production and income in Nigeria. Like other agricultural crops, cassava has a role to play in the developing economies.

Estimates of industrial cassava use suggest that approximately 16 percent of cassava root production was utilized as an industrial raw material in 2001 in Nigeria, 
10 percent of which was used as chips in animal feed while 5 percent was processed into a syrup concentrate for soft drink and about 1 percent was processed into high quality cassava flour used in biscuits and confectionary, dextrin per-gelled starch for adhesive, starch and hydrolysates for pharmaceutical, and seasoning s ( kormawa and Akoroda, 2003 ). This estimate leaves 84 percent or 28.9million tones of production for food consumption, a portion of this of course being lost in post harvest and waste. But, the methods used in achieving these are almost tedious which may lead to inefficiency use of resources and perhaps low quality and quantity of product. This implies that for the product from cassava to complete favorable in the international market, there is need to go beyond tedious method of producing which perhaps seem inefficiency (Ogbonna, et al, 2007). The method used by small and medium scale cassava processing in Imo state seem to be tedious, may lead to inefficiency use of technologically input and low product. An efficient processing technique in food could lead to increase in the quality and quantity of food available for consumption (Nelson and Donald, 1980, Ogbonna and Ezedinma, 2005). According to IFC, (2003) the small and medium processing technologies is enormous. Traditional cassava processing has a number of undesirable attributes. It is time consuming, provides low yields and lacks storages capacities. Many described it as drudgery. Mass production of cassava is possible because it tolerates wide range of soil and climatic conditions. Cassava is highly tolerate to acid soils and need no additional fertilizer especially phosphoric fertilizer because the roots of cassava form symbiotic association fungus in the soil helping cassava plants to absorb phosphorus and micronutrients from the soil (Howeler et al., 1990). Pander et al. (2000) on the other hand emphasized that cassava requires fertilization especially nitrogen, phosphorus and potassium; and that; cassava requires more nitrogen than phosphorus. Ezumah, and Okigbo (1980) suggested that farming systems such as intercropping grain legumes with cowpea, alley cropping, green maturing and animal dung would increase cassava yield than the mineral fertilizer.

\section{METHODOLOGY}

The survey was conducted in Katsina-Ala (zone A), Makurdi (zone B) and Otukpo (zone C) of Benue State, in 2016 to examine factors determining cassava production in the study area. The three agricultural zones in the area study were purposively selected based on strategic importance of cassava in the farming system of the sampled zones in the area. In each zone one Local Government Area /was selected by simple random sampling technique from the list of all Local Government Areas in the area. Then in each Local Government Area, 6 communities were similarly selected by random sampling technique, and in each community, 10 cassava farmers were equally selected through the same sampling technique. 60 Respondents were obtained from each agricultural zone making up a sample size of 180 respondents for the entire study area, Using structured questionnaires, relevant data on house hold cassava production were collected from the respondents. Data were analyzed with both descriptive and simple multiple regression statistics.

\section{Model Specification}

Categorical variables such as marital status and type of organization farmers belong was dummy coded in order to transform them into dischotomous variables. Other variables such as sex, age, level of education, farm size was entered into multiple regression equation.

Model is specified as follows;

$$
Y=\alpha+\beta_{1} X_{1+} \beta_{2} X_{2+} \beta_{3} X_{3 . .}+\beta_{14} X_{14+} U
$$

\section{Where:}

Y = Quantity of cassava produced.

A $\quad=$ Constant term

$\beta_{1}=\beta_{14}$ regression coefficients.

$X_{1}=\operatorname{sex}($ male $=1$, female $=2)$

$\mathrm{X}_{2}=$ age $($ years $)$

$\mathrm{X}_{3}=$ marital status: Single, married, widowed or divorced

$\mathrm{X}_{4}=$ level of education (level of education attainment)

$\mathrm{X}_{5}=$ farming experience (years)

$\mathrm{X}_{6}=$ fertilizer use (money spent in procuring fertilizer)

$\mathrm{X}_{7}=$ farm size (in hectares)

$\mathrm{X}_{8}=$ on-farm income (Naira)

$\mathrm{X}_{9}=$ off-farm income (Naira)

$\mathrm{X}_{10}=$ household size (actual number of people living in the household)

$\mathrm{X}_{11}=$ Major occupation

$\mathrm{X}_{12}=$ membership of organization belong to (yes $=1$, no $=2$ )

$\mathrm{X}_{13}=$ planting materials $($ money spent in procuring planting materials)

$\mathrm{X}_{14}=$ labour input (number of persons used in cassava production) 


\section{Respondents}

$\mathrm{U}=$ error term

Socio-economic Characteristics of the

Sex

Table 1 indicates that majority $(70.6 \%)$ of participants in the scheme were male while $29.4 \%$ of the respondents were female. The predominance of male in farming operation may be attributed to the tedious nature and hard work involved in various farm enterprises. Similar finding has been reported by Abdullahi (2012) which states that $84 \%$ of the farmers in Paiko Local Government Area of Niger State were male.

Age

The study further revealed that most respondents (30.0\%) belonged to the age bracket of 51-60 years, followed by $41-50$ (25.6\%), above 60 years $(20 . \%)$, 31$40(18.3 \%), 21-30(6.1 \%)$ respectively. The mean age of the respondents was 48.3 years. This implies that most of the farmers in the study areas were very active to carry out agricultural activities. Age is considered to be an important characteristic in decision process of an innovation (Agbamu, 2006).

\section{Marital Status}

Majorities (90.6\%) of the respondents were married, while $(9.4 \%)$ were single (table 1). The proportion of married persons that participated in activities was high the predominance of married individuals agrees with a study carried out by Uddin (2014) which revealed that $85.8 \%$ of the Edo state farmers were married. The predominance of married persons that participated in activities implies that they are ready to improve their livelihood and that of their families, since marriage is often associated with occupational stability and responsibility (Uddin, 2014).

\section{Level of Education}

Majority (75.5\%) of the respondents had formal education, whereas, $24.6 \%$ had no formal education (table 1). Among those with formal education, primary education accounted for $29.4 \%, 23.3 \%$ had secondary education while $22.8 \%$ had tertiary education. This implies that the respondents were literate and were more likely to utilize information on agriculture for enhanced food production. Egbule (2013) stated that education plays an important role in creating awareness in farming communities because educated people are capable of sourcing information on agricultural innovation. Benue State farmers spent $\mathrm{M}=13.1$ years acquiring formal education.

Household Size
Table 1 indicates that $42.8 \%$ of the respondents had a household size of 6-10 persons, followed by 11-15 (28.6\%), 16-20 (10.1\%), above $20(8.5 \%), 1-5(7.8 \%)$, respectively. This implies that respondents have access to family labour which will positively increase agricultural production. This implies that the respondents had a large household size. Banmeke and Ajayi (2008) noted that large household size serves as an important source of farm labour and a strong base to adopt improved technologies so as to be able to improve productivity in order to meet up with economic needs of the family. Benue State had mean household size of ( $\mathrm{M}=18$ persons).

\section{Major Occupation}

Table 1 reveals that $98.9 \%$ of the respondents had farming as a major occupation while $1.1 \%$ of the respondents were involved in farming and trading. This implies that quite a number were practicing farmers.

\section{Faming Experience}

The study further revealed that $35 \%$ of the respondents had between 6 and10 years of farming experience, followed by those who were above 20 years, $(21.1 \%), 11$ and 15 years (16.7\%), 16 and $20(14.4 \%)$ and 1 and 5 $(12.8 \%)$ of farming experience respectively. The mean farming experience was 13.1 years. This implies that quite a number of the respondents have been farming for a long time. According to Obinne (1991) farming experience enhances productivity and has shown to encourage rapid adoption of farming innovation.

\section{Farm Size}

A greater percentage $(55.6 \%)$ had a farm size of 3.4 hectares, $35.5 \%$ had 1.2 hectares, $7.8 \%$ had 5-6 hectares and $1.1 \%$ had above 6 hectares. The mean farm size was 3.5 hectares. This implies that the respondents are small scale farmers. Benue State farmers had mean farm size of $(\mathrm{M}=3.5 \mathrm{ha})$.

\section{Estimated Annual On-Farm Income}

The distribution of respondents according to their income revealed that about $53.9 \%$ of the respondents had annual income of between $\mathrm{N} 20,000$ - N100,000, while $41.1 \%$ had $\mathrm{N} 101,000-\mathrm{N} 500,000$ and 5\% had N501,000$\mathrm{N} 1,000.000$. The mean annual income was (N154, 156.50).Farmers with low income will not be able to purchase subsidized farm inputs provided by the government. This implies that respondents with high farm income are most likely to purchase government inputs. This result agrees with Abolagba (1997) who noted that farmers with high income level are in a better position to 
afford better facilities. Benue State farmers had income of (N154, 156.50).

\section{Membership of Organizations}

Distribution of the respondents according to their membership of organization revealed that $93.3 \%$ belonged to organizations and the remaining $6.7 \%$ did not belong to any. Being a member of any organization could be an avenue for accessing information on increased productivity. Asadu (2013) reported that membership of any organization is of advantage to farmers since social organization offers an effective channel for contact with large number of farmers, as well as opportunities for interactions. This enhances farmers uptake of new practice for agricultural production, processing and storage of farm produce.

\section{Fertilizer use}

The fertilizer used was procured from Federal and State government fertilizer programme. Because of the delay of the fertilizer getting to the farmers, the percentage usage by farmers was less than $50 \%$ in Benue State.
Distribution of respondents according to their annual offfarm income revealed that $53.5 \%$ had annual off-farm income of between N20,000 - N50,000, followed byN51,000 N100,000 (23.9\%), N101,000 - N150,000 (13.9\%), N151,000 - N200,000 (5.6\%) and N201,000 $\mathrm{N} 250,000(3.3 \%)$, respectively. The mean off-farm income was N38, 127.50. This is in addition to the annual on-farm income which could assist the farmer in purchasing more subsidized inputs to increase production.

\section{Planting Materials}

Distribution of respondents according to the plant materials grown by farmers' revealed that $72.2 \%$ of the respondents got their materials from International Institute for Tropical Agriculture, Ibadan and National Roots Crops Research Institute Umudike, Abia State, Nigeria. While the remaining $27.8 \%$ got their planting materials from local vendors.

\section{Labour Use}

Majority $78.9 \%$ of the respondents use family labour while the remaining $21.1 \%$ used hired labour.

\section{Estimated Annual Off-Farm Income}

Table.1: Distribution of Socio-economic Characteristics of the Respondents

\begin{tabular}{llll} 
Socio-economic & \multicolumn{2}{c}{ Benue $(\mathbf{n = 1 8 0})$} \\
Characteristics & Freq & $\%$ & Mean \\
\hline Sex: & & & \\
Male & 127 & 70.6 \\
Female & 53 & 29.4
\end{tabular}

\section{Age(years)}

$\begin{array}{lccc}21-30 & 11 & 6.1 & \\ 31-40 & 33 & 18.3 & \\ 41-50 & 46 & 25.6 & \\ 51-60 & 54 & 30.0 & \\ >60 & 36 & 20 & 48.3\end{array}$

\section{Marital Status}

\begin{tabular}{lcc} 
Single & 17 & 9.4 \\
Married & 163 & 90.6 \\
Widowed & - & - \\
Divorced & - & - \\
& & \\
Level of Education & & \\
No formal education & 44 & 24.4 \\
Primary education & 53 & 29.4 \\
Secondary education & 42 & 23.3 \\
Tertiary education & 41 & 22.8 \\
Mean of years spent in & & \multicolumn{2}{c}{13.1} \\
\hline
\end{tabular}


Household size

(number)

$1-5$

$6-10$

$11-15$

$16-20$

$>20$

Major occupation

Farming

Fishing

Farming/Trading

Hunting

Farming experience(years)

$1-5$

$6-10$

$11-15$

$16-20$

$>20$

$\begin{array}{rr}14 & 7.8 \\ 77 & 42.8 \\ 54 & 28.6 \\ 19 & 10.1 \\ 16 & 8.5\end{array}$

$178 \quad 98.9$

$-$

21.1

0 18

$23 \quad 12.8$

$63 \quad 35.0$

$30 \quad 16.7$

$26 \quad 14.4$

$38 \quad 21.1 \quad 13.1$

Farm size (hectares)

$1-2$

$3-4$

$\begin{array}{lll}5-6 & 64 & 35.5\end{array}$

$>6 \quad 100 \quad 55.6$

$14 \quad 7.8$

$\begin{array}{llllll}\text { Estimated Annual } & \text { On- } & 2 & 1.1 & 3.5\end{array}$

farm Income (Naira)

$20,000-100,000$

$101,000-500,000$

$501,000-1,000,000 \quad 97 \quad 53.9$

$74 \quad 41.1$

Fertilizer use

$9 \quad 5.0$

Fertilizer purchase from $\quad 154,156.50$

Government

$\begin{array}{llll}\text { Not purchase from } & 118 & 65.5\end{array}$

Government

$62 \quad 34.5$

Membership of

Organizations

Yes

No

$168 \quad 93.3$ 


\section{Planting materials}

IITA/NRCRI

Other vendors

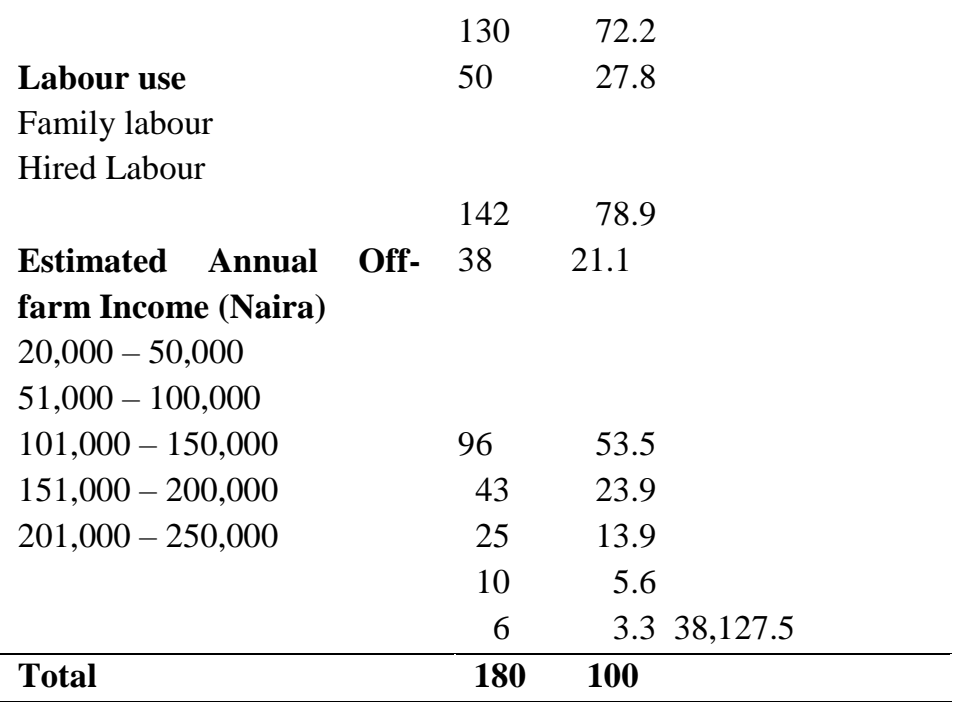

\section{2 \\ 6.7}

Source: Field Survey, 2016

\section{Socio-economic Characteristics Influencing Rural Farmers' Production Level}

Table 2 revealed that socio-economic characteristics of farmers had significant influence on farmers' production level in the activities $\left(\mathrm{F}_{(9,350)}=28.089 ; \mathrm{p} \leq 0.05\right)$. The result showed that the variables jointly predicted farmers' production level in activities $(\mathrm{R}=.419)$, and jointly accounted for $40.4 \%$ variance (adjusted $\mathrm{R}^{2}=0.404$ ) in predicting farmers' production level when all the socioeconomic characteristics were taken together. This implies that other characteristics not taken into consideration in this model may have accounted for the remaining 59.6\% variance.

Table 2 revealed the relative contribution of socioeconomic characteristics to farmers' production level in activities. The relative contributions of $\operatorname{sex}(\beta=-.078 ; \mathrm{t}=-$ $1.677 ; \mathrm{p}>0.05)$, marital status $(\beta=.049 ; \mathrm{t}=1.058$; $\mathrm{p}>0.05)$, membership of organisations $(\beta=.030 ; \mathrm{t}=.723$; $\mathrm{p}>0.05)$, on-farm income $(\beta=.032 ; \mathrm{t}=.743 ; \mathrm{p}>0.05)$, offfarm income $(\beta=.052 ; \mathrm{t}=1.220 ; \mathrm{p}>0.05)$ planting materials $(\beta=.007 ; \mathrm{t}=.166 ; \mathrm{p}>0.050)$ and labour input $(\beta$ $=0.0 .80 ; \mathrm{t}=0.842 ; \mathrm{p}>0.05)$ were not significant at predicting respondents' production level.

The relative contributions of age $(\beta=-.190 ; \mathrm{t}=-3.939$; $\mathrm{p}<.05)$, level of education $(\beta=-.202 ; \mathrm{t}=-3.804 ; \mathrm{p}<.05)$, household size $(\beta=-.108 ; \mathrm{t}=-2.507 ; \mathrm{p}<.05)$, major occupation $(\beta=.099 ; \mathrm{t}=2.023 ; \mathrm{p}<.05)$, farming experience $(\beta=.117 ; \mathrm{t}=2.694 ; \mathrm{p}<.05)$, farming size $(\beta=$ - 
most of the farmers were strong and very active to carry out agricultural activities.

Level of education was significant which suggest that literate farmers are more likely to source for agricultural related information for higher agricultural production than the illiterate farmers. This agrees with Egbule (2013) that literate respondents can enhance utilization of information on agricultural food production and that education plays an important role in creating awareness in farming communities because educated people are capable of sourcing information on agricultural innovations.

Farming experience was significant and this implies that quite majority of the respondents' have been into agricultural food production. This agrees with Obinne (1991), reported that increased farming experience enhances productivity and has shown to encourage rapid adoption of farming innovation.

Household size was significant and this implies that respondents have access to family labour which will positively increase agricultural production. This agrees with Banmeke and Ajayi (2008) noted that large household size serves as an important source of farm labour supply and a strong base to adopt improved technologies so as to be able to improve productivity in order to meet up economic needs of the family.

Table.2: Multiple Regression Analysis on the Determinants of cassava production in Benue State, Nigeria Unstandardized coefficients Standardized coefficient

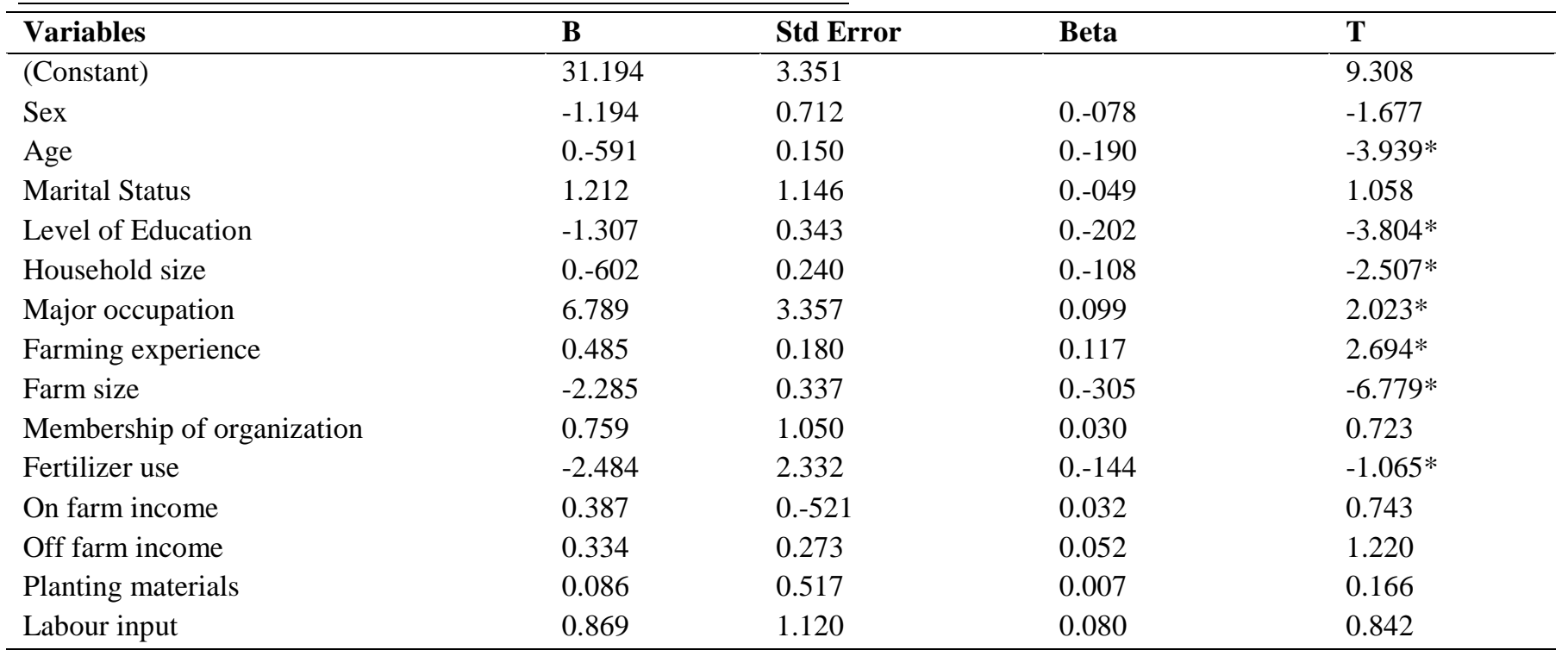

* denotes the level of significance at 0.05

A dependent variable production level of production activities, $R$ Square $=0.419$, $\mathrm{R}$ square adjusted $=0.404, \mathrm{~F}$ value $=28.089 ; \mathrm{P} \leq 0.05$.

\section{CONCLUSION AND RECOMMENDATIONS}

The result of the multiple regression analysis showed that the linear functional form largely explained the variations in the quantity of cassava produced in the study area.

In the regression analysis, the age of the farmers, the occupation, farming experience, level of education of farmers, household size, farm size, fertilizer use in production were significant. By implication these variables were critical determinants of cassava production in Benue State. Given the enormous potentials cassava production in the study area, it has become so imperative that youths be encouraged to participate effectively in cassava production, seeing that majority of the farmers are aged and will retire from active farming. This is to ensure food security. Also an effective structure should be put in place to enable the farmers benefit from the subsidy on fertilizer provided by the government, this will ensure that fertilizer get to those who need it and will in turn help the farmers expand their production . Encouraging education among the farmers will also enhance the ability to adopt improved farming techniques and boast their production.

This study, although based in Benue state may have implications for other states with similar situation. 


\section{REFERENCES}

[1] Abolagba, E.O. (1997). Socio-economic Analysis of the Acquisition and Utilization of Farming Information among Rubber Farmers in Delta State. M.Sc. Thesis, Department of Agricultural Economics and Extension Services, University of Benin, Pp 88

[2] Abdullahi, A (2012) Comparative economic analysis of rice production by adopters and non-adopters of improved varieties among farmers in Paiko Local Government Area of Niger State Nigeria. Journal of Basic and Applied Science, 20 (2) :146-151.

[3] Agbamu, J. U. (2006). Adoption and diffusion process for Agricultural Innovation Communication in Nigeria. Department of Agricultural Economics and Extension, Delta State, Asaba, Nigeria, Mathhouse Press Ltd. Victoria Island Lagos, 425pp.

[4] Asadu, A.N. (2013). Assessment of Urban Agriculture in South East Nigeria. APh.D Research findings submitted to Department of Agricultural Extension. University of Nigeria, Nsukka. Pp 104

[5] Banmeke, T. and Ajayi, M. (2008). Farmers' perception of the Agricultural Information Resource Center at Ago Are Oyo State. International Journals of Agricultural Economics and Rural Development. 1 (1): 33-39

[6] Dagon-Daji, S. D. (2005) Economics of Dry Season Onion Production and Marketing in Sokoto and Kebbi States.A ph. D thesis submitted to the Department of Agricultural Economics and Extension Usman Dan Fodio University, Sokoto.

[7] Department of Economics and Socio-Affairs (DESA)(2000) "Multi critons of Agriculture: The Case of Marketing Cooperation and juices producing companies" Institutional Journal of Agriculture (1814):543-558.

[8] Egbule, C. (2013) Gender Vulnerability and Adaptation Strategies to Climate Change Impacts on Agriculture in Niger Delta region of Nigeria. A Ph.D. Research findings submitted to Department of Agricultural Extension, University of Nigeria, Nsukka .Pp 103

[9] Ezedinma, .C. I., Okarter, C. Asumugha, G. Nweke F. (2006).Trends in Farm Labour Productivity and Implications for Cassava Industrialization in Nigeria. Proc, of the $40^{\text {th }}$ Conference of the Agricultural Society of Nigeria held at the National Root Crops Research Institute (NRCRI), Umudike, Abia State. Oct. $16^{\text {th }}-20^{\text {th }}$, pp. $109-115$.
[10]Food and Agriculture Organization (FAO), 2002 Development of the cassava processing industry and its future, pp:330-338

[11] Giroh, D. Y., Ephraim, I. J., Fannap, D., Igbinnosun, F. O. and Ogwuche, P. (2007). A Qualitative Analysis of Adoption of Natural Rubber Production Technologies Among Farmers in Southern Nigeria. Journal of sustainable Tropical Agriculture Research, vol. 21: 56-65.

[12]IFC (2003) Annual Review of Small Business Activities. International Finance Corporation (IFC), Small and Medium Enterprise Development.

[13] Nelson, P. E. and Donald K. T. (1980). Fruit and Vegetable Juice Processing Technology. Avi Publishing Co Inc.,

[14] Obinne, C. P. O (1991). Adoption of improved Cassava production technologies by small scale farmers in Bendel State. Nigeria Journal of Agriculture, Science and Technology.vol. 1(1)12 15.

[15] Ogbonna, M. C., Asumugha, G. N., Ayaegbulam, H.N. Okoye, B.C. Onwumere, J and Akinpelu A. (2007)

[16]Resource Use Efficiency in Cassava Processing in Two selected of Abia State. Pakistan Journal Social Science 49(6); 778-78; 2007

[17] Okoye, B. C., Okorji, E . C. and Asumugha, G. N. (2004) Outlook on Production Economics of Paddy Rice under Resource constraints in Ebonyi State, Proc. of the $38^{\text {th }}$ Annual conference of the Agricultural Society of Nigeria. (ASN), 17-21 Oct. 2004, Lafia, Nasarawa State. Pp 337-342.

[18] Uddin, I. (2014). Knowledge, Attitude and Practice of Herbicide use among Farmers in Edo State. An M.Sc. Research Project Submitted to Department of Agriculture Extension, University Of Nigeria, Nsukka. Pp.74.

[19] World Food Programme (1995): World Bank Survey World Bank Survey (1981). Agricultural and the Environmental Perspective for Sustainable Rural Development Erhst Cutz (Ed) John Hopkins University Press for the World Bank 